Ritrýnd grein birt 31. desember 2018

\title{
Dygðirnar í Laxdæla sögu: Efniviður fyrir mannkostamenntun
}

\author{
Róbert Jack
}

Abstract $>$ Um höfundinn $>$ About the author $>$ Heimildir

Bókmenntakennsla í anda mannkostamenntunar byggist mjög á pví að fjalla um dygðirnar í textanum. Degar tilraun var gerð með að kenna Laxdæla sögu með pessu móti purfti að taka saman dygðirnar í sögunni. Í pessari grein er að finna ítarlega greiningu á dygðum í Laxdælu. Beitt var tveimur aðferðum við að leita að dygðunum. Fyrri aðferðin fólst í að skoða pau dygðaorð sem koma fyrir í sögunni. Pannig má fá nokkuð heilsteypta mynd af peim dygðum sem höfundur Laxdælu nefnir sjálfur. Til að fá breiðari mynd af dygðunum í sögunni og jafnframt dýpri mynd af peim aðstæðum par sem dygðir koma fyrir var beitt annarri aðferð. Par var notaður listi yfir dygðir frá Jubilee-miðstöðinni á Englandi og skoðað hvað af peim mætti finna í sögunni. Í báðum tilfellum voru sams konar dæmi tekin saman til að gefa sem besta mynd af notkun orða og tilvist dygða í Laxdælu. Greiningin er rökstuðningur fyrir tilvist dygða í sögunni, getur nýst peim sem vilja kenna Laxdælu út frá dygðum og loks varpar hún fræðilegu ljósi á pær dygðir sem finna má í sögunni.

Efnisord: Laxdæla saga, dygðir, mannkostamenntun, bókmenntakennsla, Íslendingasögur, siðferði.

Mannkostamenntun í bókmenntakennslu snýst fyrst og fremst um að fjalla um dygðirnar í textanum. Dessi grein fjallar sérstaklega um dygðirnar í einni sögu, p.e. Laxdcela sögu. Grein mín Dygðir, siðferði og siðferðisproski: Að nota Íslendingasögur til mannkostamenntunar í pessu sérriti Netlu (Róbert Jack, 2018a) er eins konar undanfari að pessari grein hér en sú grein fjallar almennt um pað hvernig kenna má Íslendingasögur með áherslu á mannkostamenntun. Markmið pessarar greinar hér er prípætt. Í fyrsta lagi er henni ætlað að vera rökstuðningur fyrir pví að hægt sé að finna dygðir í Laxdœlu sem geti nýst til að nálgast kennslu á sögunni að hætti mannkostamenntunar. Í öðru lagi er greininni ætlað að vera hagnýt túlkun og greining á dygðunum í Laxdœelu fyrir pá sem vilja nýta sér söguna til dygðakennslu. Í priðja lagi varpar greinin ljósi á pær dygðir sem lesa má út úr sögunni að gefinni peirri túlkunarleið sem farin er við að finna og greina dygðirnar.

Tilurð pessarar greinar tengist rannsókn á bókmenntakennslu með áherslu á siðferðilegar dygðir sem fram fór við prjá grunnskóla haustið 2017. Rannsóknin byggðist á hugmyndum mannkostamenntunar og fólst í að lesa Laxdalu í móðurmálskennslu með sérstakri áherslu á dygðir. Sambærileg rannsókn hafði áđur verið gerð við Jubilee-miðstöðina við Háskólann í Birmingham og var tekið mið af reynslunni paðan við framkvæmd rannsóknarinnar (sbr. The Jubilee Centre for Character \& Virtues, 2014). Grunnpættir íslensku rannsóknarinnar eru raktir í grein Atla Harðarsonar, Ólafs Páls Jónssonar, Róberts Jack, Dóru Bjargar Sigurðardóttur og 
Sigrúnar Sifjar Jóelsdóttur (2018) í pessu sérhefti Netlu. Fjallað er um aðra anga rannsóknarinnar í greinum Atla Harðarsonar (2018), Ólafs Páls Jónsson (2018) og Póru Bjargar Sigurðardóttur (2018), en hér verður einungis fjallað um pau atriði rannsóknarinnar sem pykja skipta máli fyrir umræðuna í pessari grein.

Grein pessi er túlkun á einstökum textastöðum par sem greina má dygðir persóna í Laxdælu en henni er hvorki ætlað að vera heildstæð túlkun á sögunni (sbr. Frölich, 2000; Conroy og Langen, 1988; Hermann Pálsson, 1986; Madelung, 1972) né verður hér reynt að tengja niðurstöður um dygðirnar í Laxdcelu við aðrar Íslendingasögur eða dygðarit á miðöldum (sbr. Gunnar Harðarson, 1989). Að pví sögðu má læra ýmislegt af umfjölluninni hér um tilvist ákveðinna dygða og dygðir almennt í sögunni en óhætt er að segja að afar lítið hafi verið fjallað beinlínis um dygðir í Íslendingasögum, hvort heldur sem er með tilliti til fræðilegra markmiða eða kennslumarkmiða. Dó má benda á að Arthúr Björgvin Bollason (2010) hefur samið kennsluefni fyrir ungt fólk par sem athyglinni er beint að siðferði og dygðum í Njáls sögu. Dá verður í pessari grein vísað í helstu staði í fræðilegri umræðu par sem talað er um dygðir í Laxdœlu en pó að dygðir séu stundum nefndar má segja að alger skortur sé á almennri fræðilegri umfjöllun um dygðir í Íslendingasögum.

Fyrri aðferðin sem notuð var við vinnslu greinarinnar var að lesa söguna og merkja við pau orð sem vísuðu til dygða. Раð eru pá dygðir sem höfundur sögunnar hefur sjálfur nefnt. Detta er uppstaðan í fyrri yfirkaflanum í greininni sem kallast Dygðirnar á yfirborði Laxdalu. Segja má að hér sé átt við yfirborð í tvennum skilningi. Annars vegar vísar pað til pess að petta eru dygðir sem beinlínis eru nefndar í texta sögunnar. Hins vegar er raunin sú að pær dygðir sem við kynnumst með pessum hætti fá yfirleitt yfirborðslega umfjöllun í sögunni. Pannig fylgja pessum umsögnum um dygð oft engar eða litlar útskýringar. Detta er pó vissulega ekki einhlítt pví að stundum fáum við dýpri innsýn.

Önnur aðferð sem beitt var við að finna dygðir í sögunni fólst í að greina aðstæður í sögunni sem kölluðu á að persónur hegðuðu sér annaðhvort í samræmi við dygð eða löst. Í greininni er petta kallað dygðaaðstæður (sbr. Róbert Jack, 2018a). Ef skoða á dygðir í dýpri skilningi er petta vænlegri leið pví venjulega ræðir höfundur Laxdœlu ekki dygðir í tengslum við einmitt pær aðstæður sem kalla á hvað mesta togstreitu og gefa mest tilefni til djúprar umhugsunar um dygðir. Afrakstur pessarar aðferðar er í síðari yfirkaflanum sem kallast Fleiri dygðir og dygðaaðstæður í Laxdolu.

Ef aðferðirnar eru bornar betur saman má nefna að pað sem fyrri aðferðin hefur fram yfir pá síðari er að dygðirnar eru nefndar af höfundi sögunnar sjálfrar og eru pví ef til vill nær upphaflegu siðferði í sögunni. Dessi aðferð er pví ef til vill nær pví að vera túlkun á peim dygðum sem höfundur sögunnar getur hafa haft í huga. Dygðirnar sem gengið er út frá í tengslum við síðari aðferðina eru frá Jubilee-miðstöðinni en par voru 14 dygðir valdar til að nota við bókmenntakennslu og voru pær einnig notaðar sem net við lestur Laxdœlu. Fjallað er betur um petta síðar í greininni en pessi aðferð pótti nauðsynlegt til að komast nær pví að fullnýta pá möguleika sem sagan veitir til að ræða dygðir par sem hópur peirra dygða sem nefndar eru í sögunni er ekki eins fjölbreyttur og æskilegt er fyrir dygðakennslu.

Pá má geta pess að pó að pær niðurstöđur sem birtast hér séu allítarlegar og nái líkast til yfir langflest dæmi um dygð í Laxdalu er hér ekki um að ræða tæmandi upptalningu á dygðum í sögunni. Par kemur ýmislegt til. Í fyrsta lagi varð til Excel-skjal með yfir 500 línum par sem komu fyrir dygðir í sögunni og pað var ekki hægt að koma öllum peim upplýsingum fyrir í pessari grein. İ öđru lagi má efast um túlkunina sem hér er sett fram á sögunni. Dað má telja fullvíst að annar rannsakandi hefði greint sömu dygðir með öðrum hætti í Laxdcelu. Dví kunna að vera fleiri dæmi um dygðirnar í sögunni og sumt hefði ef til vill frekar mátt greina sem aðra dygð en hér er gert. Í priðja lagi hefði vissulega mátt nota aðrar dygðir og aðrar aðferðir við rannsóknina. 
Dess ber að geta að öll rannsóknin á Laxdalu byggist á sögunni í fullri lengd. Dað er hins vegar skynsamlegt að gera ráð fyrir pví að hentugra sé að kenna Laxdœlu í styttri útgáfu, sérstaklega í grunnskólum. Pví var einnig gerði úttekt á Jubilee-dygðunum í endursögn Gunnars Karlssonar (Laxdcela saga, 2017) en sú úttekt varð grunnur að námsefni fyrir Laxdœelu með áherslu á dygðamenntun (Róbert Jack, 2018b). Skemmst er frá pví að segja að niðurstöðurnar voru mjög á sömu leið um algengustu dygðirnar fyrir utan раð аð göfuglyndi var ekki eins algeng dygð. Баð kann að stafa af pví að göfuglyndi byggist mjög á pví hvað orðin göfugur og tiginn eru algeng í sögunni en pað skilar sér ef til vill ekki í endursögninni. Dessi líkindi með styttu og óstyttu útgáfunni hvað dygðir varðar er merki um að endursögnin sé vel heppnuð, að minnsta kosti að pví leyti hversu vel dygðaððtæðum er haldið inni í sögunni. Í greiningunni sem hér kemur á eftir verður eingöngu vísad í Laxdelu óstytta.

\section{Dygðirnar á yfirborði Laxdælu}

Nú verður vikið að dygðunum sem nefndar eru í Laxdœelu og fjalla má um í námsefni fyrir mannkostamenntun en varðandi skilning á dygðunum má hafa prennt í huga. Í fyrsta lagi hefur 1 fræðilegri umfjöllun um Íslendingasögur farið lítið fyrir dygðum. Stundum eru dygðaorð nefnd en engin heildstæ umfjöllun um dygðir í Íslendingasögum fannst við vinnslu pessarar greinar. Helst er fjallað um einstakar dygðir og pá gjarnan í tengslum við einstaka textastaði í Íslendingasögum. Dað er pví ekki um auðugan fræðilegan garð að gresja að pessu leyti en hér á eftir verður leitast við að vísa í pað helsta sem sagt hefur verið um dygðir í tengslum við ákveðna textastaði í Laxdelu. Í öđru lagi koma sjaldan fram útskýringar í Laxdœelu á peim dygðaorðum sem notuð eru í sögunni. Detta er ef til vill ekki óeðlilegt en pað er pó ókostur fyrir dygðamenntun. Stundum er persónum í Laxdalu lýst með dygðaorðum, til dæmis er sagt að Helgi Harðbeinsson sé stórmenni (kafli 62), Gunnar Diðrandabani sé drengur góður (kafli 69), Guðrún Ósvífursdóttir sé göfug (kafli 78) og Bolli Bollason sé kurteis og prúður (kafli 77). Detta er út af fyrir sig áhugavert en pegar petta er ekki útskýrt nánar getum við átt erfitt með að átta okkur á pví hvað raunverulega sé átt við, hvað í fari persónunnar gefi höfundi sögunnar tilefni til að gefa henni pessa einkunn. Detta er óhentugt í dygðamenntun, sem hlýtur að stefna að skilningi á peirri dygð sem verið er að tala um. Í priðja lagi er gott að hafa hugmyndina um dygðaaðstæður bak við eyrað. Sú hugmynd gengur út á að ákveðnar aðstæður kalli á að persónur hagi sér í samræmi við dygð eða löst. Slíkar aðstæður eru pví gagnlegar fyrir dygðamenntun en pær eru raunar sjaldnast til staðar par sem dygðaorð eru nefnd í sögunni.

Rétt er að taka fram að pegar sagt er hér á eftir að ekki fylgi útskýring með dygðaorði er átt við að í nánasta umhverfi orðsins sé engin umfjöllun eða aðstæður sem gætu varpað ljósi á merkingu orðsins. Раð pýðir ekki að annars staðar geti ekki komið dæmi sem styður pað að gefa persónu viðkomandi umsögn. Dað getur hins vegar reynst erfitt að tengja saman umsögn á einum stað og atburði á öðrum. Sérstaklega á pað við um grunnskólakennslu og pví verður ekki gerð tilraun hér til að varpa ljósi á dygðaorð með peim hætti.

Við að skoða pær dygðir sem orðaðar eru í sögunni var farin sú leið að finna umsagnir (oftast stök orð) sem póttu benda til að verið væri að tala um dygð og svo voru pær flokkaðar saman undir nafni einnar dygðar. Sem dæmi voru eftirfarandi orð öll tekin sem dæmi um að verið væri að tala um visku: vit, vitringur, vitur, vitsmunir, spaklegur, spakur og spekingur. Pá voru bæði neitun dygðaorðanna og andstæð orð tekin með sem dæmi um ákveðna dygð. Pannig eru orðin „drengilegur“ og „ódrengilegur“ bæði flokkuð sem dæmi um að verið sé að fjalla um drengskap í sögunni. Degar notuð er sú aðferð sem hér hefur verið lýst eru algengustu dygðirnar á yfirborði Laxdælu skörungsskapur, stórmennska, viska, kærleikur, drengskapur, göfuglyndi og kurteisi. petta eru pó ekki einu dygðirnar sem eru nefndar en einnig má nefna hyggindi, dirfsku og örlæti. Í framhaldinu verður eingöngu fjallað um algengustu dygðirnar í sögunni. 


\section{Skörungsskapur}

Degar talað er um skörungsskap í Laxdælu er sjaldnast útskýrt í hverju hann felst nákvæmlega. Pannig er til dæmis sagt um Jórunni Bjarnardóttur, Dorgerði Egilsdóttur og fleiri persónur að pær séu skörungar án pess að pví fylgi nein dæmi til útskýringar (kaflar 9, 24, einnig 7, 31). Degar engin útskýring fylgir er nær alltaf verið að tala um konur en svipuð umsögn um Helga Harðbeinsson er undantekning frá peirri reglu (kafli 62). Meulengracht Sørensen (1995, bls. 205206, 230) segir reyndar að skörungsskapur sé fyrst og fremst kvennadyg ð í Íslendingasögunum og samsvari nokkurn veginn drengskap sem aðallega sé eignaður körlum.

Í Laxdæelu eru tvö dæmi um að karlmenn séu sagðir skörulegir við fyrstu kynni fólks af peim en pað gefur til kynna að skörungsskapur sé nokkuð sem menn beri utan á sér með einhverjum hætti. Við að hitta Ólaf páa í fyrsta sinn segir fóstra Melkorku pannig að hann sé skörulegur (kafli 21) og Ólafur hinn helgi konungur segir petta einnig um Bolla Bollason (kafli 73).

Dá er gjarnan talað um skörulegar veislur (kaflar 7, 9, 27 og 69) sem ef til vill er ekki mjög hjálplegt til skilnings á hugtakinu. Reyndar má segja að engar af pessum premur fyrstnefndu tegundum af dæmum um skörungsskap séu sérstaklega gagnlegar fyrir dygðamenntun. Hér opnast hugtakið ekki nægilega mikið til að hægt sé að skilja vel hvað átt er við.

Önnur dæmi um skörungsskap eru sögð af einhverju tilefni. Mýrkjartan segir Ólaf páa skörung eftir að hann hefur kynnst honum (kafli 21). Geirmundur gnýr pakkar Dorgerði Egilsdóttur fyrir hjálp hennar við að sannfæra Ólaf páa um að leyfa sér að giftast dóttur peirra Duríði (kafli 29). Ferð Ólafssona að Dórhöllusonum pótti allsköruleg (kafli 49). Snorra goða pykir Guðrún Ósvífursdóttir skörungur pegar hún ákveður um brúðkaupsveislu sína og Dorkels Eyjólfssonar og einnig pegar hún ver Gunnar Diðrandabana fyrir Dorkatli í veislunni (kaflar 68 og 69). Dá pótti Guðrún bera fráfall Dorkels skörulega af sér (kafli 76).

Dessi dæmi um skörungsskap eru betri fyrir dygðamenntun en hin fyrri par sem pau útskýra betur hvaða eiginleika og hegðun skörungsskapur kallar á og gefa okkur færi á að meta hvort við erum sammála peirri umsögn sem höfundur gefur persónunni í hvert skipti. Öll krefja dæmin okkur jafnframt um að við setjum okkur í spor persónanna sem í hlut eiga. Stundum er um að ræða einstaka atburði en önnur dæmi gefa tilefni til að skoða frammistöðu persónunnar yfir lengri tíma. Dá er siðferðilega togstreitan í peim mismunandi mikil. Til dæmis er væntanlega ekki um neina sérstaka togstreitu að ræða pegar Guðrún hefur frumkvæði að brúðkaupsveislu sinni og Dorkels. Átökin eru hins vegar meiri pegar Guðrún ver Gunnar Diðrandabana fyrir Dorkatli en pví hefur verið haldið fram að hegðun Guðrúnar í peim aðstæðum sé dæmi um uppreisn hennar gegn kvenhlutverkinu (Helga Kress, 1980, bls. 106). Bæði Guðrún og Dorkell standa par frammi fyrir pví að purfa að ákveða hvort pau meta meira gefin loforð eða samstöðuna með maka sínum.

\section{Stórmennska}

Varðandi stórmennsku er nokkrum sinnum talað um stórmenni almennt án pess að vísað sé í persónu eđa afrek (kaflar 7, 29, 45 og 50). Einnig fá persónur pessa umsögn nokkrum sinnum án útskýringa. Dað er til dæmis stórmennskumót á Melkorku og Ólafur sonur hennar er stórmannlegur sem ungbarn (kafli 13). Einnig sér Ólafur pái að Dorgerður Egilsdóttir er stórmannleg án pess að beinlínis sé útskýrt hvað í pví felst (kafli 23).

Í flestum öðrum tilfellum er einhvers konar tilefni fyrir pessari umsögn pó að pað sé ekki alltaf mikið. Oft virðist um að ræða örlæti af einhverju tagi eða andstæðu hennar, nísku. Dannig býður Björn hinn austræni Ketilsson Unni djúpúðgu systur sinni til sín með öllu liði sínu (kafli 5). Gilli hinn gerski lætur Melkorku ekki vera í stórlátum klæðum (kafli 12). Haraldur konungur Gunnhildarson gefur Ólafi páa skip og fé (kafli 22). Ólafur feilan, Ólafur pái og Dorkell Eyjólfsson gefa stórmannlegar gjafir (kaflar 7, 30 og 58). Og Hallur Guðmundsson og Helgi Harðbeinsson 
sýna stórmennsku í viðtöku gesta (kaflar 45 og 62). Öll pessi dæmi gætu vakið pælingar um pað hvernig viðkomandi persónur hefðu getað hegðað sér öðruvísi en gefa pó varla tilefni til djúpra siðferðilegra umræðna enda virðist ekki um mikla togstreitu að ræða.

Í umræðu sinni um siðferði Íslendingasagna gerir Kristján Kristjánsson (1998, bls. 410-411) reyndar nokkuð úr mikilvægi mikilmennisins, til dæmis í Laxdalu, en að minnsta kosti eins og pað kemur fyrir á yfirborði Laxdalu virðist stórmennskuhugtakið ekki sérlega spennandi umræðuefni fyrir mannkostamenntun.

\section{Viska}

Oftast pegar sagt er að persóna sé vitur, vitringur, spekingur, hafi mikla vitsmuni eða pvíumlíkt fylgja pví engar beinar útskýringar á pví í hverju petta felst. Detta á við um umsagnir um Jórunni Bjarnardóttur, Dorkel trefil, Duríði Ólafsdóttur, Ósvífur Helgason, Gest Oddleifsson, Guðrúnu Ósvífursdóttur, Hrefnu Ásgeirsdóttur og fleiri (kaflar 9, 10, 31, 32, 33, 45). Í sumum tilfellum má ef til vill ráða af öðrum stöðum í sögunni hvort pessi umsögn á við rök að styðjast, til dæmis pegar Jórunn heldur ræðu yfir Höskuldi manni sínum um deilu hans við Hrút (kafli 19; sbr. Bouman, 1962, bls. 115). Einnig má reyna að meta réttmæti umsagnarinnar með pví að skoða hegðun persóna yfir lengri tíma. Detta er til að mynda vel hægt að gera við atkvæðamikla persónu eins og Guðrúnu. Detta gæti líka verið nálgun í dygðamenntun en eins og áður segir er í slíkri kennslu hentugra að fjalla um einstakar dygðaаðstæður en að meta hegðun persónu í mörgum köflum samtímis.

Stundum er pó gefin útskýring á pví af hverju persónunni er eignuð viska. Dannig er sagt almennt að spakir menn telji mikilvægt að mönnum komi saman í útverjum (kafli 14). Detta mætti svo sem útskýra betur en gefur okkur dæmi um viturlega hugsun. Dá segir Ólafur pái Gest Oddleifsson vitran af pví að hann ber kennsl á menn án pess að hafa séð pá áđur (kafli 33). Баð er tekið til marks um vit Ásgeirs æðikolls að hann tók vel í pað pegar Kjartan bað Hrefnu dóttur hans pví að hann áttaði sig á pví að pannig væri honum og fjölskyldu hans sýndur sómi (kafli 45). Einnig er pað talið merki um vit að hafa séð gersemar á borð við moturinn sem Kjartan gaf Hrefnu að línfé (kafli 45). Pá má nefna að Snorri goði metur misjafnlega visku Dorgils Höllusonar og Örnólfs Ármóðssonar eftir pví hvort peir muni átta sig á peim blekkingum sem Snorri leggur til að Guðrún beiti Porgils til að fá hann til að hjálpa sér að hefna Bolla (kafli 59). Hann segir Porgils hafa meira af ákafa en vitsmunum en að Örnólfur sé vitrari. Loks segir Bolli Bollason pegar hann ætlar utan að maður verði fávís við pað að kanna ekki fleiri staði en Ísland (kafli 72).

Detta eru helstu dæmin um visku á yfirborði Laxdælu og pað hlýtur að vekja athygli hversu fjölbreytt pau eru pó að hér hafi verið sleppt skyldum dæmum um klókindi (sbr. van den Toorn, 1955, bls. 68). Баð sem pó skiptir mestu máli fyrir okkar samhengi er að pó að dæmin hljóti að teljast upplýsandi um hugmyndir um visku í fornöld pá gefa pau ekki tækifæri til mikilla siðferðilegra vangaveltna. Hér er ekki að finna neinar sérstakar dygðaaðstæður.

\section{Karleikur}

Flokka má ýmis orð sem merki um kærleika, sérstaklega orð sem byrja á ást-, og orðin blíðu og kærleika. Í raun mætti telja vináttu hér með líka. Dessi orð eru algeng í Laxdælu og eru notuð við nokkur tilefni. Greina má fleiri en eina leið til að tala um kærleika í sambandi karls og konu en Frölich (2000, bls. 95-96, 158-179) hefur fjallað ítarlega um hjónabönd og önnur ástarsambönd í sögunni. Gjarnan er sagt að „góðar ástir“ takist með hjónum, eins og Porgerði Dorsteinsdóttur og Herjólfi, Ólafi páa og Dorgerði Egilsdóttur, Kjartani og Hrefnu, Guðrúnu og Porkatli og loks Bolla Bollasyni og Dórdísi Snorradóttur (kaflar 7, 24, 45, 69 og 70). Dá er sagt að Dórður Ingunnarson unni konu sinni lítt (kafli 32). Um hjónaleysi er sagt að pað séu kærleikar með peim, til dæmis Pórði og Guðrúnu og Kjartani og Guðrúnu (kaflar 34 og 43). 
Alloft er talað um ást á börnum. Pannig ann Höskuldur sonum sínum Bárði og Ólafi páa (kaflar 9 og 13). Dórður goddi leggur ást á Ólaf páa (kafli 16). Ólafur pái og Dorgerður unna Bolla Dorleikssyni (kafli 27). Ólafur pái ann Kjartani og Bolla (kaflar 33 og 48). Og Guðrún ann Bolla syni sínum og einnig Herdísi dóttur hans (kaflar 70 og 76).

Einnig er töluvert af dæmum um að kærleikur, blíða og ást séu notuð til að tjá vináttu eða að minnsta kosti sátt á meðal jafningja eða einstaklinga í svipaðri stöðu. Í öllum pessum tilfellum er um að ræða samband karla. Stundum er um að ræða unga menn, eins og Bolla og Kjartan (kaflar 39, 40 og 45). Stundum er petta samband Íslendings og heldri manns, eins og Ólafs páa við Mýrkjartan Írakonung, Harald Noregskonung og Hákon jarl hinn ríka (kaflar 21, 22 og 29). Kjartan Ólafsson og Dorkell Eyjólfsson eiga líka í slíku vinfengi við konunga (kaflar 40, 43 og 74) en gerð hefur verið grein fyrir sterkum tengslum Laxdœla við konunga (Ármann Jakobsson, 1998). Fleiri dæmi má nefna en par er merkingin svipuð og hér hefur verið nefnt.

Ekki verður séð að orð sem byrja á vin- vísi til annars veruleika en pau orð sem flokkuð voru undir kærleika og fjallað var um hér síðast. Undantekningin er pó sú að par er á einum stað fjallað um samband kvenna og sagt að Dorgerður Egilsdóttir og Auður, fyrrverandi kona Dórðar Ingunnarsonar, séu vinkonur (kafli 53). Hér er einnig algengt að lýsa sambandi Íslendings og konungs svona. Pannig er vinátta með Ólafi páa og bæði Haraldi konungi og Mýrkjartani (kaflar 21 og 22). Einnig er vinátta með Kjartani og Ólafi Tryggvasyni og Bolla Bollasyni og Ólafi hinum helga Haraldssyni (kaflar 43 og 73).

Í framangreindum dæmum um kærleika og vináttu eru sjaldan gefnar einhverjar nánari skýringar á kærleikanum eða vináttunni pó að gjarnan fylgi lýsingar á pví að persóna hafi gefið annarri gjafir. Stundum má ef til vill líta á gjöf sem kærleiksmerki en oft parf pó að túlka hana svo að eitthvað meira hafi búið að baki, eins og fjallað verður um í tengslum við örlæti. Degar talað er um vináttu er stundum gefin útskýring á pví í hverju vináttan fólst pannig að vinur veitir vini sínum einhverja aðstoð. Dannig er á einum stað sagt að vinir Gests Oddleifssonar hafi gjarnan leitað ráđa hjá honum (kafli 33). Hrútur Herjólfsson telur sig sýna Dorleiki Höskuldssyni vinskap með pví að drepa Eldgrím sem var að stela hrossum Dorleiks pó að Dorleikur sjái petta að vísu öðruvísi (kafli 37). Og einnig er sagt að Kjartan Ólafsson og Kálfur Ásgeirsson skipti félagi pví sem peir áttu saman í vinskap (kafli 44). Pó að hér séu einhverjar útskýringar er ekki hægt að segja að neitt af peim dæmum sem finna má um kærleika og vináttu gefi tilefni til verulegra umræðna nema pá kannski dæmið um Hrút og Dorleik en Porleikur telur Hrút hafa svívirt sig í pessum samskiptum.

•ó að kærleiksorð séu víða notuð í sögunni má á sumum öðrum stöðum greina kærleika í háttalagi persóna og par væri pví hugsanlegt að tala um dygðaaðstæður. Dannig má álykta um kærleika hjá Mýrkjartani og Melkorku dóttur hans. Mýrkjartan roðnar pegar hann áttar sig á pví að dóttursonur hans er kominn til hans (kafli 21) og má taka pað sem merki um pessa dygð. Annar vottur um kærleika er pegar Mýrkjartan býður Ólafi konungdóm eftir sinn dag (kafli 21). Dá má ráđa kærleika Melkorku móður Ólafs í garð fólks síns á Írlandi af pví að hún spyr margs um föður sinn og frændur á Írlandi og einnig fóstru sína, sem hún vildi gjarnan fá til sín til Îslands (kafli 22).

\section{Drengskapur}

Orðin drengur, drengilegur og ódrengilegur koma nokkrum sinnum fyrir hvert í Laxdalu en drengskapur er líklega sú dygð í Íslendingasögunum sem fengið hefur mesta umfjöllun fræðimanna. Dar má sérstaklega nefna umfjöllun Sigurðar Nordals (1942, bls. 186-188) sem tengir orðið við traust en Vilhjálmur Árnason (1985, bls. 34, 1991, bls. 158) leggur áherslu á staðfestu hins drengilega manns (sbr. Kristján Kristjánsson, 1998, bls. 410). Dá segir Sigurður hugrekki einnig pátt í dygðinni drengskap (sbr. van den Toorn, 1955, bls. 140). 
Hér er líklega algengara en um önnur dygðaorð að tala um löstinn og segja að persónur séu ódrengilegar. Einnig virðist hér algengara að einhvers konar útskýring fylgi umsögninni um persónurnar. Bó eru nokkur dæmi um að ekki sé útskýrt í hverju drengskapurinn felst. Pannig er drengskapur Bárðar Höskuldssonar, Kálfs Ásgeirssonar, Gunnars Diðrandabana og Gellis Dorkelssonar óútskýrður (kaflar 25, 40, 69 og 74).

Drengskapur er til umfjöllunar hjá hjónunum Vigdísi Ingjaldsdóttur og Dórði godda (sbr. Meulengracht Sørensen, 1995, bls. 252-254) en Vigdís er eina konan sem sögð er haga sér drengilega. Dá umsögn fær hún hjá Dórólfi frænda sínum fyrir að hjálpa honum að dyljast og komast undan Ingjaldi Sauðeyjargoða pó að Dórður goddi hefði pegið fé af Ingjaldi fyrir að aðstoða hann við að klófesta Dórólf (kafli 15). Dað er pví sérstaklega áhugavert og undirstrikar andstæðuna á milli peirra hjóna að Dórður goddi fær tvisvar pau ummæli í sama kafla að hafa hagað sér ódrengilega. Fyrst frá Ingjaldi, sem telur Pórð hafa komið Dórólfi undan, og svo frá Vigdísi fyrir að hafa pegið fé fyrir að svíkja Dórólf.

Önnur persóna sem vænd er um að haga sér ódrengilega er Geirmundur gnýr en svo segir Duríður Ólafsdóttir kona hans um hann pegar sem hann ætlar að fara af landi brott án pess að taka dóttur sína með sér og án pess að skilja eftir fé (kafli 30). Pá vænir Kjartan Bolla ekki beinum orðum um ódrengskap en biður hann að vera drengilegri í samskiptum við pá Hjarðhyltinga en samhengið er hvarfá sverði og motri sem Kjartan sakar Laugamenn um að bera ábyrgð á (kafli 46). Einnig er Dorkell að Hafratindum sagður hafa látið ódrengilega pegar hann var tekinn af lífi (kafli 52). Рað kann pó að hafa verið sagt honum til háðungar par sem hann varð vitni að pví pegar Kjartan var veginn, gerði ekkert til að aðstoða hann en sagði að Kjartan hefði verið huglaus (kafli 49). Loks segir Lambi Dorbjarnarson Porgils Hölluson gera sér ódrengilega afarkosti pegar hann býður honum að fara að Helga Harðbeinssyni eða verða annars veginn (kafli 61). Í pessu sambandi er áhugavert að Dorgilsi er síðar lýst sem drengilegum í sjón (kafli 63). Öll pessi tilvik par sem persóna er talin ódrengileg eru dygðaððstæður par sem samhengið gefur tilefni til pess að dygð persónunnar sé metin.

Einnig koma fyrir nokkur jákvæð dæmi um drengskap sem líta má á sem dygðaaðstæður enda fylgir úrskýring á aðstæðum. Björn Ketilsson pykir mæla drengilega pegar hann tjáir hug sinn um аð hann vilji frekar flýja Noreg en að bíða eftir að menn Haraldar konungs hins hárfagra drepi sig og fólk sitt (kafli 2). Pá segir Höskuldur Dala-Kollsson Gilla hinn gerska haga sér drengilega pegar hann segir honum að ambáttin sem hann æetlar að selja Höskuldi sé mállaus í stað pess að leyna pví (kafli 12). Loks segir Ólafur konungur Tryggvason pað drengilegt af Kjartani Ólafssyni að gangast við pví að hafa viljað brenna konung inni (kafli 40).

\section{Göfuglyndi}

Undir göfuglyndi eru hér flokkuð pau tilvik par sem orðin tiginn og göfugur koma fyrir. Oftast eru pessi tvö orð notuð með sambærilegum hætti pó að orðið tiginn vísi að jafnaði til hærra settra einstaklinga en orðið göfugur. Að minnsta kosti í köflum 41 og 43 virðast orðin tiginn og ótiginn vísa til fólks af konunglegum ættum eða ekki. Algengast er að orðin vísi ekki til neinnar ákveðinnar persónu heldur til tiginna manna eða göfugra frænda. Pá er eins og verið sé að sýna góða stöðu ákveðinna persóna innan sæmdarveldisins með pví að benda á tengsl peirra við slíkar persónur en Meulengracht Sørensen (1995, bls. 130-131) leggur einmitt áherslu á að göfgi einstaklings felist fyrst og fremst í tengslum við merka ætt. Pannig fær Ketill flatnefur góðar viðtökur af tignum mönnum í Skotlandi, Unnur djúpúðga bauð tignum mönnum til veislu, Melkorka segir Ólaf son sinn eiga göfuga frændur á Írlandi, Dorleikur Höskuldsson var með tignum mönnum í kaupferðum, Kjartan Ólafsson á göfuga frændur á Íslandi, Porkell Eyjólfsson var með tignum mönnum í Noregi og Dorleikur Bollason var handgenginn hinum tigna Ólafi konungi helga (kaflar 4, 7, 20, 25, 43, 68 og 70). Í pessum tilfellum er engin útskýring að baki umsögninni nema pá helst að viðkomandi hafi háa félagslega stöðu. Einnig er talað um göfugt kvonfang en pær Gjaflaug Arnbjarnardóttir og Guðrún Ósvífursdóttir eru metnar svo (kaflar 
20 og 68). Ekki er útskýrt hvers vegna Ásgeir Snartarson og Ásgeir æðikollur eru sagðir göfugir (kaflar 31 og 45).

Ekkert af pessum dæmum eru sérstaklega gagnleg í dygðakennslu. Í raun má efast um að göfuglyndið í framangreindum dæmum sé eiginleg dygð. Рað kann að vera að í pví sæmdarsiðferði sem almennt er talið ríkja í Íslendingasögum (sbr. Torfa H. Tulinius, 2001, bls. 57; Kristján Kristjánsson, 1998, bls. 409; Svavar Hrafn Svavarsson, 2009, bls. 248), sé félagsleg staða álitin dygð en pað er varla gert núna. Að minnsta kosti stríðir pað gegn peirri hugmynd að dygð sé eitthvað sem maður hefur áunnið sér eða tilheyrir persónu manns sjálfs. Ein og sér staða manns sem fyrirmaður eða ríkur einstaklingur getur pví ekki kallast dygð. Í sæmdarveldi kann pó að hafa verið uppi hugmynd um að maður öðlaðist einungis ákveðna stöðu með pví að vera mannkostum búinn og pví hlyti maður í góðri stöðu að hafa pá til að bera. Dannig hafi sumir blátt blóð í æðum og náttúrulega yfirburði sem birtist í andlegu og líkamlegu atgervi og félagslegri stöðu. Einnig kemur til greina að talið sé að góð staða gefi manni ákveðna eiginleika. Раð að hafa mannaforráð gefi manni til að mynda aðra sýn á lífið og geri manni kleift að rækta með sér dygð göfuglyndisins sem aðrir eigi erfitt með að gera.

Hvað sem pessu líður eru nokkur dæmi par sem orðið göfugur er útskýrt með einhverjum peim hætti sem bent getur til dygðar. Dannig vill Björn Ketilsson gera að dæmi göfugra manna og flýja Noreg (kafli 2). Einnig er sagt í framhaldi af peirri lýsingu á Ólafi páa að hann hafi verið vinsæll og vel metinn að hann hafi pótt göfugasti sonur Höskulds (kafli 24). Dorgerður Egilsdóttir eggjar syni sína til að hefna Kjartans og segir pá ólíka göfugum frændum sínum pví peir hefni ekki (kafli 53). Đá er sagt um Guðrúnu Ósvífursdóttur í lok sögunnar að hún hafi verið fyrsta nunna á Íslandi og einnig einsetukona og í framhaldinu er sagt að hún hafi verið ,göfugust jafnborinna kvenna hér á landi“" (kafli 78). Í öllum pessum tilfellum eru útskýringarnar frekar punnar en gefa pó einhverja mynd af göfuglyndi. Að pessu sögðu er hér varla um sérlega áhugaverðar dygðaаðstæður að ræða pó að vel megi til að mynda reyna að setja sig í spor sona Porgerðar og velta fyrir sér hvað manni finnist göfugt.

\section{Kurteisi}

Orðið kurteisi má tengja við hugmyndir um riddaramennsku og ljóst er að slíkar hugmyndir hafa haft áhrif á Laxdcelu (Madelung, 1972, bls. 151-152, 155-156; Kramarz-Bein, 1994). Eins má bó segja um kurteisi og áður var sagt um göfuglyndi að pað er á mörkum pess að geta talist eiginleg dygð, að minnsta kosti á okkar tíma mælikvarða. Undir pennan flokk falla orðin kurteisi, kurteis og kurteislegur ásamt einu tilviki af orðinu prúđur. Í tveimur tilfellum pegar Ólafur pái og Bolli Dorleiksson eru sagðir kurteisir er ekki útskýrt hvað átt er við (kaflar 13 og 28). Annars vísa öll tilfellin til pess hvernig fólk ber sig sýnilega. Stundum er meiri áhersla á skart og klæðaburð í pví sambandi en á öðrum stöðum er áherslan á framkomu eða hegðun. Í enn öðrum tilfellum verður svo ekki greint parna á milli.

Dæmi um áherslu á skart eða útbúnað er hvernig Ólafur pái og fylgdarlið hans býr vel og kurteislega um tjaldbúð sína (kafli 26). Skýrustu dæmin varða pó Guðrúnu Ósvífursdóttur og son hennar Bolla Bollason. Guðrún er sögð svo kurteis að skart annarra kvenna er sagt hégómi í samanburði (kafli 32). Dá er Bolli Bollason í miklum skartklæðum pegar hann kemur heim frá útlöndum og hann er enn fremur kallaður „Bolli hinn prúði““ (kafli 77). Dess er síðan getið að konur hafi ekki getað haft augun af Bolla og skarti hans og er sagt að hann ríði í slíkri kurteisi vestur í sveitir.

Helstu dæmin um áherslu á hegðun eða framkomu eru pegar Hallur Guðmundsson biður Kjartan Ólafsson að sýna pá kurteisi að taka pátt í leik með öðrum og Kjartan verður við pví (kafli 45). pá er sagt að Hrefna kona Kjartans hafi verið harmprungin eftir víg Kjartans en að hún hafi pó borið sig kurteislega „,pví að hún var við hvern mann létt í máli“ (kafli 50). Í pessum dæmum má segja að greina megi nútímamerkingu orðsins. Đó er erfitt að segja að pessi dæmi um kurteisi séu 
almennt sérlega áhugaverð fyrir dygðamenntun. Sjaldnast er um að ræða skýrar dygðaaðstæður nema kannski í tveimur síðastnefndu dæmunum.

\section{Fleiri dygðir og dygðaaðstæður í Laxdælu}

Hér að framan hefur komið í ljós að nýta má sumar dygðir sem liggja á yfirborði Laxdœelu til að ræða um dygðir. Баð virðist pó ljóst að heilmargar dygðaaðstæður fari forgörðum ef við nýtum einungis dygðir sem beinlínis eru nefndar í sögunni. Ef pessari leið er fylgt um dygðir verður ekki fjallað um marga stærstu atburði Laxdaelu. Til að dygðaаðstæður fari ekki forgörðum og vegna pess að pað er ekki ástæða til að ætla að allar dygðir sem finna má í sögunni séu nefndar af höfundi hennar er ástæða til að skoða hvort fleiri dygðir finnist í henni.

Út frá sjónarhorni mannkostamenntunar má spyrja hvort réttu dygðirnar sé að finna í Laxdcelu svo að nemendur geti fengið par heildstætt yfirlit yfir hinar mikilvægustu dygðir. Dó verður að teljast vafasamt að gera slíka kröfu pví að pað er vandasamt að segja til um í eitt skipti fyrir öll hvaða dygðir einstaklingur parf til að lifa góðu lífi. Pá eru engin merki um að Laxdæela sé sérstaklega byggð á neinni slíkri hugmynd. Dví verður ekki gerð sú krafa til einnar sögu eins og Laxdœlu að hún gefi heilsteypt yfirlit yfir allar mikilvægar dygðir. Dygðamenntun sem byggðist á Laxdælu fæli pví miklu heldur í sér einhvers konar tilviljunarkennt úrval dygða sem vonandi samanstæði af mikilvægum dygðum pó að ekki sé hægt að gera kröfu um að allar mikilvægar dygðir komi fyrir.

Í rannsóknarverkefninu sem pessi grein byggist á var talið nærtækast að nýta lista yfir dygðir sem Jubilee-miðstöðin hefur notað við sambærilegt verkefni á Englandi (The Jubilee Centre for Character \& Education, e.d.). Til að undirbúa kennsluefni fyrir nemendur valdi Jubileemiðstöðin átta aðaldygðir til að vinna með og sex aðrar dygðir. Við lestur á Laxdœlu kom reyndar í ljós að sumar dygðanna á lista Jubilee póttu ekki hentugar eins og pær komu fyrir. Dó var gjarnan heppilegt að setja skylda dygð í staðinn.

Dannig pótti erfitt að koma beinlínis auga á réttlæti (e. justice) í Laxdelu. Dað kann að helgast af peim proska sem einkennir samfélag sögunnar en pað virðist einfaldlega ekki einkennast af réttlæti, eins og við nútímamenn myndum skilgreina pað. Eðlilegra pótti að tala um sanngirni og varð pað hugtak fyrir valinu. Einnig pótti skrýtið að tala um náð eða miskunnsemi (e. mercy). Bæði er pað óparflega kristilegt orðalag og pá virðast pær aðstæður sem kalla á miskunnsemi einfaldlega ekki pað algengar í sögunni, p.e. að einn hafi örlög annars í hendi sér en hlífi honum (sjá pó kafla 58 og 64). Eðlilegra pótti að tala um sáttfýsi en færa má fyrir pví rök að sáttfýsi eða ósáttfýsi persóna sé eitt stærsta viðfangsefnið í Laxdalu. Loks pótti eðlilegra að tala um prautseigju en styrk (e. strength).

Auðvitað má deila um greiningar á einstökum textastöðum en stóra myndin ætti að vera nokkuð skýr og taka má niðurstöðurnar saman með eftirfarandi hætti. Oftast koma fyrir eftirfarandi dygðir: kærleikur (e. love), örlæti (e. generosity), sáttfýsi, hugrekki (e. courage), göfuglyndi (e. nobility), sanngirni, heiðarleiki (e. honesty), sjálfsagi (e. self-discipline) og prautseigja. Af peim 14 dygðum sem lagt var upp með var hins vegar lítið sem ekkert fjallað um eftirfarandi fimm dygðir: Auðmýkt (e. humility), pjónustu (e. service), vongleði (e. hope), pakklæeti (e. gratitude) og trúfesti (e. faith). Баð kemur ef til vill ekki á óvart að auðmýkt, pjónusta og pakklæti skuli ekki einkenna mjög persónur í Laxdalu. Óvíst er pó með vongleði og trúfesti. Eflaust má hér kenna greinandanum að einhverju leyti um раð аð pær dygðir töldust sjaldgæfar.

Af peim Jubilee-dygðum sem oftast fundust eru einungis tvær pær sömu og fundust á yfirborði Laxdœlu, p.e. kærleikur og göfuglyndi. Ekki er ástæða til að fjalla nánar um pessar tvær dygðir par sem pessi síðari leit greip að mestu sömu dæmin og fundust á yfirborði Laxdœlu. Varðandi hinar sjö algengu dygðirnar sem eftir standa verður sérstaklega fjallað um tilfelli par sem um dygðaаðstæður er að ræða enda eru pau dæmi mun áhugaverðari fyrir dygðamenntun en hin, eins og áður hefur verið fjallað um. 


\section{Örlæti}

Flest tilfellin sem metin voru hér sem örlæti snúast um gjafir og góðvild einhvers konar í tengslum við heimsóknir (sbr. van den Toorn, 1955, bls. 58-59). Örlætið felst pá fyrst og fremst í pví að taka vel á móti fólki og gefa pví góðar gjafir pegar pað fer aftur. Detta er dygð pví pað er væntanlega ekki skylda að koma pannig fram. Dó verður að segja að í sæmdarsiðferði sé pað að gefa gjafir ekki endilega dygð í peim skilningi að gefandinn hugsi fyrst um pað sem piggjandanum kemur vel. Dað lítur frekar út fyrir að gjafir séu liður í að treysta böndin við vini og vandamenn (sbr. Helga Porláksson, 2001, bls. 94-96) og pað er sannarlega við hæfi að velta fyrir sér, eins og Derrida (1992) gerir, hvort í raun sé hægt að gefa eitthvað par sem gjöfin virðist ávallt skuldbinda piggjandann með einhverjum hætti.

Fjöldamörg dæmi eru um pað að konungar gefi Íslendingum gjafir, oftast 1 kveðjuskyni, (kaflar 13, 19, 21, 22, 40, 43, 73, 74 og 78) og hið sama er upp á teningnum pegar menn halda úr veislum á Íslandi (kaflar 7, 9, 23, 27, 29, 45 og 69). Fleiri dæmi um örlæti par sem eiginhagsmunaástæður virðast ljóslega leika stórt hlutverk er pegar Pórður goddi býður Ólafi páa í fóstur og gefur honum arf eftir sig (kafli 16). Dórður styrkir greinilega stöðu sína í samfélaginu með pessu. Рað er ef til vill svipað dæmi pegar Ólafur pái býður Bolla til sín til að sættast við Dorleik (kafli 27). Öðruvísi eiginhagsmunir eru ráđandi pegar Ólafur pái gefur Geirmundi kaupskip, að pví er virðist til að losna við hann úr landi (kafli 30).

Dæmi um dygðaaðstæður par sem örlætið virðist ekki eins eiginhagsmunadrifið, pó að dæmi um nísku leynist innan um, er pegar Unnur djúpúðga kemur til Íslands og vantar stað fyrir sig og fólkið sitt. Helgi bróðir hennar býður henni einungis að vera með helming fólks síns en Björn býður öllum að vera hjá sér (kafli 5). Einnig virðist Unnur sjálf sýna örlæti pegar hún gefur förunautum sínum land (kafli 6), meðal annars Dala-Kolli (sem hún gifti Dorgerði barnabarn sitt), og pegar hún gefur Erpi præli sínum frelsi (kafli 6). Dá virðist Mýrkjartan sýna örlæti er hann býður Ólafi páa konungdóm eftir sinn dag (kafli 21) og annað jákvætt dæmi um örlæti er pegar Höskuldar öfundar Ólaf son sinn ekki af virðingunni sem hann fær (kafli 24) en pað hlýtur að teljast örlæti í sæmdarveldi að gefa eftir virðingu.

Orðið „örlátur“ kemur annars einu sinni fyrir í Laxdæelu og einu sinni orðið „örlæti“ en bæði skiptin eru í kafla 73 par sem talað er um Bolla Bollason. Í raun má segja að par sé merkingu orðsins vel lýst eins og pað kemur fyrir í Laxdælu. Sagt er að Bolli sé framgjarn og vilji vera fyrir öðrum mönnum og að honum hafi tekist pað vel pví að hann sé örlátur. Detta gefur einmitt til kynna að pað að vera örlátur við aðra hafi verið leiðin til að afla sér vina og virðingar og fara fyrir mönnum.

\section{Sáttfýsi}

Sáttfýsi í Laxdæelu má eins og örlæti skilja í samhengi við sæmdarsiðferði Íslendingasagna. Eitt skýrt einkenni pessa siðferðis er að maður parf að hefna eða fá pað bætt ef venslamaður manns hefur verið drepinn eða eitthvað annað hefur verið gert á manns hlut. Í pessu ljósi verður hefnd leið til að heimta sóma sinn aftur. Dað er pví ef til vill eðlilegt að sáttfýsi sé ekki eins almenn í Laxdœelu og gera má rád fyrir að hún sé í dag. Engu að síður ganga sumar persónur lengra í að sættast eða sættast ekki en aðrar og vel má skoða pað sem dygð eða löst.

Í sjálfu sér virðist ekkert vera snúið við að skilja út á hvað sáttfýsi gengur. Erfiðara er að átta sig á pví hvort eðlilegt sé að sættast í hverju tilfelli fyrir sig pví pað er ekki víst að pað að vera ófús til að sættast í einhverju tilfelli merki endilega að maður sé ósáttfús yfirleitt. Đað getur vel verið að maður sé að leita eftir pví sem er sanngjarnt og gera má ráð fyrir að peir sem leiti hefnda líti svo á. Samt má vel velta fyrir sér hvenær hvað á við. Dað sem mat á sáttfýsi kallar iðulega á er einhvers konar heildarmat á aðstæðum til að geta betur skilið réttmæti pess að fara fram með peim hætti sem um ræðir. Petta getur auðvitað reynst erfitt par sem dygðaaðstæðurnar eru ekki ljósar fyrr en við skiljum petta heildarsamhengi. 
Í Laxdœelu eru nokkur dæmi um misklíð par sem persónur taka ólíkt á málum. Dessi mál eru ef til vill líka ágæt dæmi um dygðapælingar sem við missum af ef við skoðum bara dygðirnar sem við fundum á yfirborði Laxdæelu. Eitt dæmi um ósætti í sögunni er pegar Höskuldur vill skipta arfi jafnt með öllum sonum sínum, líka Ólafi páa sem ekki er getinn í hjónabandi, en samkvæmt lögum áttu óskilgetnir synir ekki rétt á arfi til jafns við skilgetna syni (kafli 26). Par sem Porleikur leggst gegn pví blekkir Höskuldur hann til að sampykkja stærri gjöf til handa Ólafi en lögin leyfðu. Af pessu verður ósætti milli Ólafs og Dorleiks. Ósáttfýsi Dorleiks verður ljósari við pað að Bárður albróðir hans vill sættast við Ólaf. Ólafur sýnir svo sáttfýsi sína með pví að bjóðast til að taka Bolla, son Dorleiks, í fóstur (kafli 27). Hér má velta fyrir sér hvað hefði verið eðlilegt að gera fyrir pá Ólaf og Dorleik.

Með sambærilegum hætti má velta fyrir sér ósætti Duríðar og Geirmundar (kaflar 29 og 30) og eins pegar Dórður Ingunnarson vill ekki láta elta Auði fyrrverandi konu sína pegar hún leggur til hans og særir (kafli 35). Hér má spyrja hvort Duríður og Auður hafi verið ósáttfúsar eða bara viljað öðlast sæmd á ný. Eins má spyrja hvað Pórður leggi hér til grunvallar peirri ákvörðun sinni að sættast við Auði.

Líkt og sæmdarsiðferðið getur ýtt undir ósáttfýsi getur pað einnig ýtt undir sáttfýsi. Рað má sjá glöggt hjá Ólafi páa í tveimur málum en varla er nokkur persóna í Laxdœelu eins friðelskandi og Ólafur (sbr. Bouman, 1962, bls. 122). Fyrst vill hann sætta Porleik hálfbróður sinn og Hrút föðurbróður sinn pegar peir deila (kaflar 37 og 38). Séð í hagnýtu ljósi getur pað bæði veikt stöðu pína ef venslamenn pínir takast á innbyrðis og einnig getur pað valdið vafa um hvoru liðinu pú átt að fylgja ef annar myndi nú vega hinn. Detta verður enn átakanlegra í hinu málinu sem Ólafur tengist en pað er ósættið sem verður annars vegar á milli Bolla, Guðrúnar og peirra Laugamanna og hins vegar heimilismanna Ólafs í Hjarðarholti eftir að Kjartan kemur heim. Dar er auðsætt að á meðan Guðrún og Kjartan geta ekki sæst og skiptast á að gera hvort öðru óleik á víxl vill Ólafur pái umfram allt sætta fólk (kaflar 44-49). Detta endar eins og allir vita með pví að Bolli drepur Kjartan. Ólafur pái vill pá ekki láta drepa Bolla eins og synir hans vilja pó (kaflar 49-51). Kannski má útskýra pað með pví að Bolli var fóstur- og bróðursonur hans og pví hefði mátt líta svo á að hann væri skyldugur til að hefna hans.

Í pessu máli öllu og eftirmálum eru allmörg tækifæri til að ræða sáttfýsi og ósáttfýsi annarra persóna en Ólafs páa. Spyrja má um hegðun Kjartans pegar hann vill ekki heimsækja Laugamenn, vill ekki piggja hesta af Bolla, dreitir Laugamenn inni og kúgar Dórarinn í Tungu til að selja ekki Bolla og Guðrúnu land (kaflar 44, 45 og 47). Einnig má spyrja um sáttfýsi Bolla pegar hann býður Kjartani hesta til að blíðka hann, pað að hann skuli láta Guðrúnu sannfæra sig um að fara að Kjartani og pað аð hann skuli á endanum vega Kjartan (kaflar 45, 48 og 49). Íhuga má háttalag Guðrúnar pegar hún fær Hrefnu til að sýna sér moturinn, pað að hún virðist standa að baki pví að Ósvífurssynir stela sverði Kjartans (kafli 46), pað að hún skuli verja stuldinn á motri Hrefnu (kafli 46), að hún skuli eggja bræður sína og Bolla til að fara og vega Kjartan eftir að hann hafði dreitt pau inni (kafli 48), að hún skuli sýna meinfýsni í garð Hrefnu eftir að Kjartan var veginn (kafli 49) og loks að hún skuli ekki gleyma vígi Bolla og sjá til pess tólf árum síðar að hans sé loks hefnt (kafli 59). Pá má nefna pátt Porgerðar Egilsdóttur í að sannfæra syni sína um að drepa Bolla eftir að Ólafur pái er dáinn (53 og 54). Loks má tala um pátt Snorra gođa í að skipa málum pannig að víg pessi takist af (kaflar 59 og 71) og pátt bæði Ólafssona og Bollasona í að ljúka deilumálunum (kafli 71). Hér er pví um fjölmargar dygðaaðstæður að ræða og spyrja má hvernig sagan hefði getað farið ef einhver eða allar framangreindar persónur hefðu verið sáttfúsari.

\section{Hugrekki}

Dar sem hugrekki virðist mikilvægt í sæmdarsiðferði almennt (sbr. van den Toorn, 1955, bls. 8587) eru merkilega fá orð í Laxdæelu sem beinlínis vísa til hugrekkis og pau virðast ekki endilega vera notuð par sem hugrekki er helst að finna. Raunar eru orðin djarfur, óslær (djarflegur), djarflegur og dáðlaus gjarnan notuð til að eggja menn til athafna, sérstaklega til hefnda (kaflar 
47 og 53) og í eitt skiptið segist Ólafur pái gerast svo djarfur að pora að setjast hjá Porgerði Egilsdóttur (kafli 23). Í leit að hugrekki er pví vænlegast að líta á aðstæður par sem gera má ráð fyrir að fólk fyndi til ótta en pað gerir pað ekki eða lætur óttann að minnsta kosti ekki ráða för. Fyrst má nefna að Ólafur pái virðist sýna hugrekki pegar hann kemur að landi á Írlandi (kafli 21). Hann hræðist ekki að fást við Íra og er tilbúinn að berjast ef parf. Hér er gagnlegt að skoða ólík viðbrögð Arnar, sem er með Ólafi í för og virðist óttast mjög viðskipti við Írana. Á einum stað biður Olafur menn sína að „,herða hugina“. Reyndar veit Ólafur að Mýrkjartan Írakonungur er afi hans og hefur pví ástæðu til að ætla að hann muni taka sér vel. Dað gefur pó einungis enn frekari ástæðu til að ræða forsendur dygðarinnar hugrekkis. Hverju skiptir pekking pegar kemur að hugrekki? Ólafur sýnir svo aftur hugrekki er hann berst við draug Hrapps (kafli 24).

Dó að Cook (1992, bls. 53) sé á öđru máli virðist ekki á neinn hallað pegar pví er haldið fram að sá sem sýni mest hugrekki í Laxdąu sé Kjartan Ólafsson (sbr. Madelung, 1972, bls. 163) pó að hugrekki hans sé reyndar stundum á mörkum pess að geta talist dygð (sbr. Ármann Jakobsson, 1998, bls. 373-374) og ætti jafnvel frekar að kalla fífldirfsku. Hugrekki Kjartans hverfist svo um tvo menn, annars vegar Ólaf konung Tryggvason og hins vegar Bolla Dorleiksson, og jafnframt má tala um tvö mismunandi svið. Fyrra sviðið er í Noregi, en par sýnir Kjartan hugrekki með pví аð pora að keppa í sundi við ópekktan sundmann sem reynist vera konungurinn (kafli 40). Dar spyr hann Bolla fyrst hvort Bolli vilji keppa við sundmanninn en Bolli telur pað ekki á sínu færi. Í pessum kafla leggur Kjartan einnig áherslu á að láta konunginn ekki kúga sig til að taka kristni og segist meira að segja vilja freista pess að brenna hann inni. Bolli segir petta ekki hyggilegt. Degar konungur segist svo vita ráðagerðina gengst Kjartan hiklaust við henni, sem væntanlega er til marks um hugrekki.

Síðara sviðið par sem Kjartan sýnir hugrekki umfram Bolla er pegar hann kemur heim og illindin verða á milli Hjarðhyltinga og Laugamanna. Kjartan tekur að minnsta kosti af skarið á meðan Bolli situr hjá, hvað sem segja má um sanngirni athafna Kjartans. Áður en Kjartan er drepinn af Bolla eru gefnar nokkrar vísbendingar um hugrekki Kjartans eða fífldirfsku. Kjartan lætur ekki vondan draum Áns hrísmaga aftra för sinni og vill ekki vera sakaður um að pora ekki að halda leiðar sinnar (kafli 48). Degar hann verður var við fyrirsátina sem honum er gerð snýr hann pegar að Ósvífurssonum pó að liðsmunurinn sé nokkur og ef til vill er pað hugrekki líka að kasta frá sér sverðinu í lokin og leyfa Bolla að drepa sig (kafli 49).

Aðrir sem virðast sýna hugrekki eru Án hrísmagi, sem tekur fullan pátt í bardaganum pegar Kjartan er veginn og fer fyrstur inn í selið í aðförinni að Bolla pegar aðrir hika (kaflar 49 og 55). Pá virðist Dorkell Eyjólfsson sýna hugrekki með pví að fara einn að Grími og Helgi Harðbeinsson sömuleiðis pegar hann hleypur út úr selinu pegar sótt er að honum (kaflar 57, 58 og 64). Loks mætti ef til vill tína til fleiri aðstæður par sem persónur virðast sýna hugrekki, ekki síst konur, en dæmi um pað er glíma Vigdísar Ingjaldsdóttur við að halda frænda sínum Dórólfi á lífi (kaflar 14 og 15; sbr. Frölich, 2000, bls. 78).

\section{Sanngirni}

Dæmi eru um pað í Laxdælu að persónum sé pannig lýst að pær séu ekki líklegar til að vera sanngjarnar í samskiptum sínum við aðra. Dannig er pví spáð um Dorleik Höskuldsson að hann verði „engi jafnaðarmaður“ (kafli 9). Sagt er um Víga-Hrapp að hann vildi ekki láta sinn hlut pó að hallaði á aðra og hann vildi ekki bæta pað er hann gerði á hlut annarra, auk pess sem hann var ágangssamur við nágranna sína (kaflar 10 og 17). Loks vildi Hallur bæði kjósa og deila veiðifangi pví sem hann hafði aflað með Dórólfi (kafli 14).

Fyrir utan petta virðast vera að minnsta kosti tvær stórar dygðaaðstæður í sögunni par sem gott er að velta fyrir sér sanngirni persónanna eða réttlæti. Í fyrra tilfellinu er Höskuldur Dala-Kollsson 1 aðalhlutverkinu en Snorri goði í hinu síðara. Fjalla má um sanngirni með pví að velta fyrir sér hvort Höskuldur hafi gert rétt pegar hann skipti arfi á milli sona sinna (kafli 26) en ádur 
var fjallað um petta dæmi í ljósi sáttfýsi. Eins og við munum fer Höskuldur á svig við lög og blekkir son sinn Dorleik pegar hann gefur Ólafi gjafir. Hér vaknar spurningin hvort Höskuldur sé í raun sanngjarn eða ekki. Voru lögin kannski ranglát og var petta pví sanngjarnt svona eða hefði Höskuldur átt að fara að lögum? Detta er pví ef til vill ekki dæmi um sanngirni en pað gefur tilefni til að ræða hvað sé sanngjarnt og hvað ósanngjarnt. Skoða má petta út frá peim sjónarmiðum sem virðast eiga við í sæmdarsiðferði og einnig á okkar tímum.

Hitt dæmið varðar pað pegar Snorri goði leggur til að Dorgils Hölluson verði blekktur til að hjálpa Guðrúnu og Bollasonum við að hefna Bolla Dorleikssonar (kaflar 59, 60 og 65). Guðrún lofar að giftast Porgilsi og engum öðrum samlendum manni en hefur í huga að giftast Porkatli Eyjólfssyni sem pá er staddur í Noregi. Hér virðist engan veginn komið fram af sanngirni eða réttlæeti gagnvart Dorgilsi. Einnig er ljóst að Snorra goða er umhugað um að öll víg sem leiddi af vígi Kjartans takist af. Рað virðist pví ákveðin sáttfýsi búa að baki tillögum hans auk pess sem hann leggur til að pannig verði staðið að pví að hefna Bolla að af pví hljótist sem minnst eftirmál. Hér má pví velta fyrir sér hvernig sanngirni og sáttfýsi takast á. Varðandi spurninguna um sanngirnina í pessu öllu koma svo fleiri persónur við sögu pví Guðrún framkvæmir blekkinguna en fleiri vita af henni. Pá framfylgir Porgils sjálfur hluta af rádagerð Snorra með pví að setja Dorsteini svarta og Lamba að pví er virðist algera afarkosti til að fá pá til að taka pátt í aðförinni аð Helga Harðbeinssyni (kafli 61). Loks lætur Snorri goði svo drepa Porgils (kafli 67). Petta mál allt er pví nokkuð flókið og snúið getur verið að dæma um hver ætti að bera sök á óréttlætinu sem parna birtist.

\section{Heiðarleiki}

Nokkur dæmi eru um heiðarleika og óheiðarleika í Laxdælu. Dannig er Gilli hinn gerski heiðarlegur við Höskuld Dala-Kollsson er hann segir honum að ambáttin sem hann æetlar að selja honum sé mállaus (kafli 12). Höskuldur verður einnig að teljast heiðarlegur pegar hann segir Jórunni konu sinni allan sannleikann um samskipti sín við ambáttina sem hann sængaði hjá (kafli 13). Í tengslum við petta dæmi sjáum við einn af kostum dygðanálgunarinnar. Að minnsta kosti samkvæmt siðferði okkar tíma er pað hvorki aðdáunarvert af manni að kaupa ambátt né að sofa hjá henni. Hér virðist Höskuldur pví hafa einhverja lesti en um leið er erfitt að hafna pví að hann sé heiðarlegur við Jórunni, og pað telst pá vera dygð. Styrkur dygðanálgunarinnar felst pá í pví að geta varpað ljósi á pessa ólíku pætti í persónuleika persónanna. Einnig má í sama kafla velta fyrir sér andstæðum í persónuleika ambáttarinnar Melkorku par sem hún blekkir menn og lætur pá halda að hún geti ekki talað en um leið lýsir pað ákveðinni prautseigju af hennar hálfu að geta neitað húsbóndanum um aðgang að rödd sinni.

Áhugavert dæmi um heiðarleika er pegar Dorkell Eyjólfsson finnur fyrir Gunnar Diðrandabana sem vill ekki segja til nafns pví hann hafði vegið mann og vill leynast (kafli 69). Pá segir Porkell að sé hann sú kempa sem menn segja pá vilji hann ekki leyna nafni sínu. Gunnar bregst við með pví að viðurkenna hver hann er. Hér má pví tengja heiðarleika við pað að vera mikilmenni. Баð séu einungis lítilmenni sem reyni að dyljast.

Dæmi um óheiðarleika er pegar Geirmundur gnýr leynir Ólaf páa pví að hann ætli með honum til Íslands (kafli 29). Pá virðast ráđagerðir og brögð Dórðar Ingunnarsonar og Guðrúnar Ósvífursdóttur til að losna úr hjónaböndum frekar óheiðarleg en ósanngjörn (kaflar 34 og 35). Рað er ekki víst að pað sé ósanngjarnt af Guðrúnu gagnvart Porvaldi að vilja skilja við hann en hún fór heldur óheiðarlega að við skilnaðinn og hið sama má segja um samskipti bórðar við Auði. Pá má vissulega telja ráđagerð peirra Snorra goða og Guðrúnar gagnvart Porgilsi, sem áđur var nefnd, óheiðarlega (kaflar 59, 60 og 65). Öll pessi dæmi kalla á spurningar um hvernig hefði verið hægt að breyta öðruvísi svo að yrði í meira samræmi við dygð og hvort einhverjar persónur hafi ekki átt neitt betra skilið en að vera blekktar. 


\section{Sjálfsagi}

Баð gefast nokkur tækifæri til að fjalla um sjálfsaga í Laxdælu. Eitt peirra er pegar Jórunn lemur Melkorku með sokkum og Melkorka svarar með pví að kýla Jórunni í nefið pannig að blæddi (kafli 13). Hér er áhugavert að skoða hvort reiðin sem hvor um sig finnur til í aðstæðunum getur talist réttlætanleg og hvort viðbrögðin séu í samræmi við pað. Dað er nefnilega ekki útilokað að reiði sé réttlætanleg ef maður hefur verið beittur ósanngirni en færa má rök fyrir pví að slíkt eigi við pegar Bolli reiðist Guðrúnu, Lambi reiðist Ólafssonum og Dorgils Hölluson reiðist Guðrúnu (kaflar 49 og 65). Pá má velta fyrir sér hvort Dórólfur hefði mátt sýna meiri sjálfsaga pegar hann drepur Hall fyrir að vilja bæði kjósa og deila (kafli 14). Eins má spyrja um sjálfsaga Guðrúnar pegar hún krefur Porvald mann sinn um miklar gjafir og eins sjálfsaga Dorvaldar pegar hann gefur Guðrúnu kinnhest (kafli 34).

Guðrún Ósvífursdóttir virðist annars sýna meiri sjálfsstjórn en aðrar persónur sögunnar (sbr. Bouman, 1962, bls. 120). Sjálfsstjórn hennar hverfist fyrst og fremst um víg peirra Kjartans og Bolla en pó að hún leiki lykilhlutverk í atburðarásinni og merki séu um að hún upplifi sterkar tilfinningar verður ekki séð að hún missi stjórn á skapi sínu. Er pað kannski sérstaklega áhugavert í ljósi pess að pegar hún er kynnt til sögunnar er hún sögð örlynd kona (kafli 32), sem gefur til kynna að hún hafi síðan lært að stjórna skapi sínu. Meðan Kjartan er veginn spinnur hún heilmikið garn (kafli 49) og pegar menn koma til að vega Bolla vill hún fyrst vera hjá honum en pegar hann hafnar pví gengur hún út og fer að pvo léreft sín (kafli 55). Öll framkoma hennar daginn sem Bolli er veginn er raunar ótrúleg. Hún pvær í læknum eins og ekkert sé að gerast á meðan maður hennar er veginn, hún spyr menn svo tíðinda, brosir við Helga Harðbeinssyni pegar hann hefur purrkað blóð Bolla af vopni sínu með blæjuenda hennar og síðan gengur hún áleiðis með peim sem fóru að Bolla og ræðir við pá á leiðinni.

Loks má velta fyrir sér sjálfsaga peirra sem sagan segir okkur að upplifi miklar tilfinningar, ekki síst sorg (sbr. van den Toorn, 1955, bls. 88-91). Detta á til að mynda við um Hrefnu eftir að Kjartan er veginn en hún ber sig kurteislega og er létt í máli (kafli 50).

\section{Prautseigja}

Prautseigja virðist heldur vera dygð kvenna en karla í Laxdaelu. Hún kemur til að mynda fram hjá Unni djúpúðgu sem gefst ekki upp í erfiðum aðstæðum í Skotlandi, læur byggja skip á laun, kemst burt til Íslands og kemur sér upp búi hér (kaflar 4 og 5). Pá virðast Melkorka, Auður, Vigdís Ingjaldsdóttir, Dorgerður Egilsdóttir, Guðrún Ósvífursdóttir, Jórunn Bjarnardóttir, Gunnhildur drottning, Duríður Ólafsdóttir og Ingibjörg Tryggvadóttir konungssystir allar sýna prautseigju með einum eða öðrum hætti, eins og sjá má á pví hvernig pær hafa haft áhrif á söguna (Cook, 1992, bls. 37-38). Konur sýna gjarnan prautseigju í hefndarhug sínum en Steblin-Kamenskij (1981, bls. 85) tengir prautseigju einmitt við hefndarskylduna í Íslendingasögunum. Pær halda við minningunni um mikilvægi hefndarinnar og sjá til pess að hún nær fram að ganga eða pá að pær beinlínis grípa til vopna sjálfar, sem fátítt er pó í Íslendingasögum.

Duríður sættir sig ekki við að Geirmundur maður hennar yfirgefi landið án pess að taka annaðhvort dóttur sína með sér eða skilja eftir fé. Hún kemur pví sjálf barninu í skipið til hans og stelur sverði hans Fótbít (kafli 30). Auður hefnir sín á Dórði Ingunnarsyni með pví að leggja til hans par sem hann sefur í lokrekkju (kafli 35). Dað eru Dorgerður og Guðrún sem sjá til pess að Kjartans og Bolla sé hefnt. Eftir lát Ólafs páa, sem var andvígur pví að vega Bolla, er pað Dorgerður sem eggjar syni sína til að fara að Bolla og er með í för pegar hann er veginn til að tryggja að allt gangi petta nú eftir (kaflar 53-55). Svipað má segja um Guðrúnu, sem heldur hefndarhuginum lifandi í tólf ár, par til synir hennar eru orðnir nógu gamlir til að hefna föður síns. Pá kemur hún af stað ferlinu sem leiðir til pess að Bolla er hefnt (kafli 59 og 60). Ekkert af pessum dæmum ber merki um mikla sáttfýsi en kona sem á pessum tíma rekur slík mál til enda hlýtur að teljast vera prautseig. Detta eru pví dygðaaðstæður. 


\section{Lokaorð}

Í upphafi greinarinnar kemur fram að markmið hennar sé einkunn prípætt. Í fyrsta lagi hljóta pau fjölpættu dæmi um dygðir og dygðaaðstæður sem fundust í Laxdæelu að vera rökstuðningur fyrir pví að sagan sé gagnleg til að nota til mannkostamenntunar. Dæmin virðast auk pess ekki einungis vera fjölmörg heldur eru mörg peirra einnig djúpar dygðaaðstæður par sem gott er að velta fyrir sér dygðum og löstum persóna. Jafnframt má segja að finna megi allmargar dygðir í sögunni en pað hlýtur að teljast kostur í dygðamenntun. Dessu tengt er greinin pá í öðru lagi túlkun á flestum dygðaаðstæðunum sem kemur til greina að nota í kennslu og er vonandi að pað geti gagnast peim sem vilja kenna söguna með pessum hætti. Í priðja lagi varpar greinin ljósi á ýmsar dygðir sem finna má í sögunni. Eins og áður hefur verið getið um má setja fyrirvara við aðferðina sem notuð er en pó verður ekki annað séð en hér sé að finna langsamlega ýtarlegustu greiningu á dygðum í nokkurri Íslendingasögu til pessa. Auk pess koma dygðirnar sem fundust pað oft fyrir í Laxdœelu að umfjöllunin er allskýr sönnun fyrir tilvist peirra par.

\section{The virtues in Laxdæla saga: Material for character education}

Character education through the teaching of literature is first and foremost based on the teaching of virtues in stories. The teacher looks for virtues in the literature with her students and then these virtues are discussed to improve the students' understanding of virtue concepts and hopefully make them more aware of virtues in their own lives. In preparation for a research project where Laxdæla saga, one of the Icelandic sagas, was taught in this way, the story was analysed in terms of the virtues identified there. This article contains a detailed analysis of the virtues found in Laxdæla saga. The analysis is an argument for the claim that virtues exist in the Icelandic sagas. It can be used by those who want to teach Laxdæla saga, for example, by means of discussing these virtues and furthermore throws scholarly light on the virtues found in the saga.

Two methods were used for searching for virtues in Laxdæla saga. The first method aims at being as close to the text of the saga as possible by researching the virtue vocabulary used in the saga itself. The words in the text that could refer to virtues were found and systematically categorized. Each category also included the opposite of the virtue; that is, the vice. Sometimes this appears in the form of a negation of the virtue and sometimes there is a word for the opposite. The most common virtues noted using this method may be rendered as vigour (skörungsskapur), noblemindedness (stórmennska), wisdom, love, manliness (drengskapur), nobility and courteousness (kurteisi), although their translation into English is by no means straightforward.

Examples of each virtue identified in the saga by using this first method, are listed and explained in the article. Generally a distinction can be made between two categories of examples, where one kind is more useful in character education than the other. The first category is when a virtue is mentioned without any explanation. The second occurs when the virtue of a character is further described or illustrated. Usually the virtue is presented in the form of a view that the character holds or a deed the character has done.

Sometimes when a virtue is explained we can talk of a virtue situation. This refers to a situation, in which a character in the saga finds herself, which helps to evaluate the character's virtues. This may be a relatively mundane situation or one charged with moral tension. Although virtue situations are quite common in Laxdæla saga they usually do not come to light, however, by using the first method of looking for virtue words. This called for the second method, because for character education it is important to find examples where the characters' behaviour is explained in some way but is also provides food for thought as to how one could behave differently. 
In the second method, a list of virtues from The Jubilee Centre for Character \& Virtues at the University of Birmingham was used to see which of them could be found in the story. The majority of examples discovered using this method were cases of virtue situations. The most common virtues using this method where love, generosity, conciliatoriness (or mercy), courage, nobility, fairness (or justice), honesty, self-discipline and endurance (or strength).

These two different methods may be useful for the teaching of Laxdæla saga in different ways. The first method may help teachers and students identify virtues on the surface of Laxdæla saga. This is helpful in the beginning, or for less advanced students, to become acquainted with the virtues. The second method, on the other hand, helps them spot virtue situations that can spark discussions and lead to a more profound understanding of the characters in the story and of the virtues themselves.

Keywords: Laxdæla saga, virtues, character education, teaching literature, Icelandic sagas, ethics.

\section{Um höfundinn}

Róbert Jack (robjack@hi.is) er nýdoktor og aðjunkt við Menntavísindasvið Háskóla Íslands. Hann hefur m.a. birt skrif um mannlegan proska, heimspekilega samræðu og pjónandi forystu.

\section{About the author}

Róbert Jack (robjack@hi.is) is a postdoctoral researcher and adjunct lecturer at the School of Education, University of Iceland. He has, among other things, published on human development, philosophical dialogue, and servant leadership.

Dessi grein er hluti af rannsóknarverkefni sem var unnið með styrk úr Rannsóknarsjóði Íslands (nr. 163230-051) og pakka ég sjóðnum fyrir stuðninginn. Ég pakka einnig Atla Harðarsyni, Ólafi Páli Jónssyni, Póru Björgu Sigurðardóttur, kennurum og öðrum peim sem komu að verkefninu fyrir samstarfið og gagnlegar umræður um efnið. Loks vil ég pakka ritrýnum fyrir gagnlegar ábendingar.

\section{Heimildir}

Arthúr Björgvin Bollason. (2010). Lifsleikni Njálu: Siðfrææileg umhugsunarefni fyrir ungt fólk. Kópavogur: A4.

Ármann Jakobsson. (1998). Konungasagan Laxdæla. Skírnir, 172, 357-383.

Atli Harðarson. (2018). Ógæfa Bolla Dorleikssonar: Hugleiðing um hvernig Laxdæla saga leggur spurningar fyrir lesanda sinn en svarar peim ekki. Netla - veftímarit um uppeldi og menntun. Sérrit 2018 - Bókmenntir, listir og grunnpattir menntunar. Menntavísindasvið Háskóla Íslands. Sótt af http://netla.hi.is/serrit/2018/ bokmenntir_listir_menntun/02.pdf

Atli Harðarson, Ólafur Páll Jónsson, Róbert Jack, Dóra Björg Sigurðardóttir og Sigrún Sif Jóelsdóttir. (2018) Laxdæla saga og orðaforði um siðferði. Netla - veftímarit um uppeldi og menntun. Sérrit 2018 - Bókmenntir, listir og grunnpattir menntunar. Sótt af http://netla.hi.is/serrit/2018/bokmenntir_listir_menntun/01.pdf

Bouman, A. C. (1962). Patterns in old English and old Icelandic literature. Leiden: Universitaire Pers Leiden.

Conroy, P. og Langen, T. C. S. (1988). Laxdæla saga:Theme and structure. Arkiv för nordisk filologi, 103, 118-141.

Cook, R. (1992). Women and men in Laxdæla saga. Skáldskaparmál, 2(2), 34-59.

Derrida, J. (1992). Given time: I. Counterfeit money. Chicago: University of Chicago Press.

Frölich, D. (2000). Ehre und Liebe: Schichten des Erzählens in der Laxdcela saga. Frankfurt am Main: Peter Lang. Gunnar Harðarson (ritstjóri). (1989). Drjár pýðingar larðar frá miðöldum. Reykjavík: Hið íslenska bókmenntafélag. 
Helga Kress. (1980). „Mjǫk mun pér samstaft pykkja“: Um sagnahefð og kvenlega reynslu í Laxdæla sögu. Í Valborg Bentsdóttir, Guðrún Gísladóttir og Svanlaug Baldursdóttir (ritstjórar), Konur skrifa til heiðurs Önnu Sigurðardóttur (bls. 97-109). Reykjavík: Sögufélag.

Helgi Porláksson. (2001). Fé og virðing. Í Samdarmenn: Um heiður á pjóðveldisöld (bls. 91-134). Reykjavík: Hugvísindastofnun Háskóla Íslands.

Hermann Pálsson. (1986). Leyndarmál Laxdalu. Reykjavík: Bókaútgáfa Menningarsjóðs.

Kramarz-Bein, S. (1994). ,Modernität“ der Laxdæla Saga. Í H. Uecker (ritstjóri), Studien zum Altgermanischen: Festschrift für Heinrich Beck (11. bindi) (bls. 421-442). Berlin: Walter de Gruyter.

Kristján Kristjánsson. (1998). Liberating moral traditions: Saga morality and Aristotle's megalopsychia. Ethical Theory and Moral Practice, 1(4), 397-422. doi:10.1023/A:1009990801822

Laxdela saga (endursögn Gunnars Karlssonar). (2017). Kópavogur: Menntamálastofnun.

Madelung, A. M. A. (1972). The Laxdeela saga: Its structural patterns. Chapel Hill: The University of North Carolina Press.

Meulengracht Sørensen, P. (1995). Fortalling og are: Studier i islandingesagaerne. Oslo: Universitetsforlaget.

Ólafur Páll Jónsson. (2018). Laxdæla sem fóður fyrir gagnrýna hugsun. Netla - veftímarit um uppeldi og menntun. Sérrit 2018 - Bókmenntir, listir og grunnpattir menntunar. Menntavísindasvið Háskóla Íslands. Sótt af http:// netla.hi.is/serrit/2018/bokmenntir_listir_menntun/06.pdf

Róbert Jack. (2018a). Dygðir, siðferði og siðferðisproski: Að nota Íslendingasögur til mannkostamenntunar. Netla - veftímarit um uppeldi og menntun. Sérrit 2018 - Bókmenntir, listir og grunnpattir menntunar. Menntavísindasvið Háskóla Íslands. Sótt af http://netla.hi.is/serrit/2018/bokmenntir_listir_menntun/09.pdf

Róbert Jack. (2018b). Laxdcela saga: Dygðakennsla. Sótt af https://klb.mms.is/ - /laxdaela/dyga-kennsla-robert-jack/?_k=p1xwwu

Sigurður Nordal. (1942). Íslenzk menning. Reykjavík: Mál og menning.

Steblin-Kamenskij, M. I. (1981). Heimur Íslendingasagna (Helgi Haraldsson pýddi). Reykjavík: Iðunn.

Svavar Hrafn Svavarsson. (2009). Honour and shame. Gripla, 20, 241-256.

The Jubilee Centre for Character \& Virtues. (e.d.). Resources for pupils: Anne Frank. Sótt af https://www.jubileecentre.ac.uk/userfiles/jubileecentre/pdf/KVResources/ResourcesforPupils/KV-ANNEFRANK_RESOURCESFORPUPILS.pdf

The Jubilee Centre for Character \& Virtues. (2014). Knightly virtues: Enhancing virtue literacy through stories. Sótt af https://www.jubileecentre.ac.uk/userfiles/jubileecentre/pdf/KVPDF/KnightlyVirtuesReport.pdf

Torfi H. Tulinius. (2001). Virðing í flóknu samfélagi. Í Scemdarmenn: Um heiður á pjóðveldisöld (bls. 57-89). Reykjavík: Hugvísindastofnun Háskóla Íslands.

Van den Toorn, M. C. (1955). Ethics and moral in Icelandic saga literature. Assen:Van Gorcum.

Vilhjálmur Árnason. (1985). Saga og siðferði: Hugleiðingar um túlkun á siðfræði Íslendingasagna. Tímarit Máls og menningar, 46(1), 21-37.

Vilhjálmur Árnason. (1991). Morality and social structure in the Icelandic sagas. Journal of English and Germanic Philology, 90(2), 157-174.

Dóra Björg Sigurðardóttir. (2018). Siðfræði í bókmenntakennslu. Netla - veftímarit um uppeldi og menntun. Sérrit 2018 - Bókmenntir, listir og grunnpattir menntunar. Menntavísindasvið Háskóla Íslands. Sótt af http:// netla.hi.is/serrit/2018/bokmenntir_listir_menntun/11.pdf

Róbert Jack. (2018).

Dygðir í Laxdæla sögu: Efniviður fyrir mannkostamenntun.

Netla - veftímarit um uppeldi og menntun. Sérrit 2018 - Bókmenntir, listir og grunnpættir menntunar.

Menntavísindasvið Háskóla Íslands. Sótt af http://netla.hi.is/serrit/2018/bokmenntir_listir_menntun/10.pdf

https://doi.org/10.24270/serritnetla.2019.23 